\title{
AOR
}

Selected Papers of \#AolR2020:

The $21^{\text {st }}$ Annual Conference of the

Association of Internet Researchers

Virtual Event / 27-31 October 2020

\section{ILLUMINATI(NG) THE SEARCH PROCESS: THEORIZING THE RESEARCH PRACTICES OF "ALTERNATIVE" OR "CONTROVERSIAL" RESEARCH}

\author{
Yvonne M. Eadon \\ University of California, Los Angeles
}

Approaching the study of conspiracy theorizing as an academic can be epistemically and methodologically tricky. Few studies tackle the topic using participant-centered interviewing, as many individuals whom scholars may want to call conspiracy theorists understandably eschew the label. ${ }^{1}$ The project outlined in this abstract will theorize the research practices of individuals who look into topics that have been labeled "conspiracy theories," using participant-centered grounded theory interviewing methods.

Many prominent conspiracy theorists frequently employ the phrase "do your own research," as a kind of call to action: Kony Rowe, creator of the 9/11 Truth film Loose Change, responded to accusations that his film contained inaccuracies with the following statement: "We know there are errors in the documentary, and we've actually left them in there so that people discredit us and do the research for themselves." Rob Brotherton quotes the notorious David Icke, propagator of the theory that all powerful figures are secretly humanoid lizards: "The conspirators leave subtle symbols of their plot lying around, Icke says, and 'when you know what you're looking for, it starts jumping out at you."'3

Many such well-known conspiracy theorists at once emulate academic rhetoric and subvert it, challenging its epistemic authority. ${ }^{4}$ Emma A. Jane and Chris Fleming have characterized conspiracy theorizing as a kind of "folk sociology." 5 On the whole, however, academics, journalists, politicians, and non-conspiracists, often dismiss people they perceive as conspiracy theorists out of hand by virtue of the supposed

\footnotetext{
${ }^{1}$ Jaron Harambam and Stef Aupers, “'I Am Not a Conspiracy Theorist': Relational Identifications in the Dutch Conspiracy Milieu," Cultural Sociology 11, no. 1 (March 1, 2017): 113-29, https://doi.org/10.1177/1749975516661959.

${ }^{2}$ David Aaronovitch, Voodoo Histories: The Role of the Conspiracy Theory in Shaping Modern History (New York, NY: Riverhead Books, 2010), 14.

${ }^{3}$ Rob Brotherton, Suspicious Minds (New York, NY: Bloomsbury Sigma, 2015), 227.

${ }^{4}$ Jaron Harambam and Stef Aupers, "Contesting Epistemic Authority: Conspiracy Theories on the Boundaries of Science," Public Understanding of Science 24, no. 4 (May 1, 2015): 466-80, https://doi.org/10.1177/0963662514559891.

${ }^{5}$ Emma A. Jane and Chris Fleming, Modern Conspiracy: The Importance of Being Paranoid (New York, NY: Bloomsbury Academic, 2014), 11.

Suggested Citation (APA): Eadon, Y. (2020, October). Illuminati(ng) The Search Process: Theorizing the Research Practices Of "Alternative" or "Controversial" Research. Paper presented at AoIR 2020: The 21 Annual Conference of the Association of Internet Researchers. Virtual Event: AolR. Retrieved from http://spir.aoir.org.
} 
danger and ignorance of their ideas. ${ }^{6}$ Such dismissiveness is itself risky, however, as recent research suggests that ostracizing such "conspiracist" individuals may result in their unwillingness to approach or believe sources that may contradict their epistemic approach(es). ${ }^{7}$ This paper asks: is there indeed a certain kind of research style that can be attributed to individuals looking into conspiratorial topics? Or are there many kinds of research practice extant within research communities that form around so-called "conspiratorial," alternative, or controversial topics?

Previous scholarship has examined how conspiracy theories spread online; ${ }^{8}$ addressed the question of what conspiracy theorists believe and why; ${ }^{9}$ asked whether or not conspiracy theorizing is a reasonable form of sense-making; ${ }^{10}$ and characterized the socio-cultural effects of conspiracy theories. ${ }^{11}$ Yet, the research practices of those who explore topics that have been labeled "conspiracy theories," remain under-examined and under-theorized. Existing at the convergence of three interdisciplinary areas of scholarship-the study of conspiracy theory/ies, information seeking and behavior (e.g., research practices), and archival studies--this project will present preliminary dissertation research. The data will come from in-depth, qualitative interviews with individuals who regularly conduct research into one of three topics: the assassination of John F. Kennedy, the 1947 incident in Roswell, New Mexico, and the Missing 411 phenomenon. Interviews are semi-structured, addressing participants' experiences of different modes of research: within a research community, in isolation (by themselves), and with the help of a reference archivist or librarian, among others that may emerge. This paper will also feature reflexive grounded theory analysis of my own feminist standpoint as a researcher and interviewer.

Some conspiracy theory scholarship discusses "conspiracy theorists" as a group of individuals whose epistemological orientation to their topics of interest is relatively homogenous, antithetical to that of the researcher, and often, inherently wrong. As a feminist qualitative researcher using grounded theory interviewing methods, my methodological priorities revolve around putting participants at the center of the research process, and recognizing and reconciling power imbalances in the course of data gathering. ${ }^{12}$ In such a way, and with the help of interview participants, I have

\footnotetext{
${ }^{6}$ Jack Braitch, Conspiracy Panics: Political Rationality and Popular Culture (Albany, New York: State University of New York Press, 2008), 20.

${ }^{7}$ R. Kelly Garrett, Daniel Sude, and Paolo Riva, "Toeing the Party Lie: Ostracism Promotes Endorsement of Partisan Election Falsehoods," Political Communication 0, no. 0 (October 11, 2019): 1-16, https://doi.org/10.1080/10584609.2019.1666943.
}

${ }^{8}$ Alice Marwick and Rebecca Lewis, "Media Manipulation and Disinformation Online" (Data \& Society Research Institute, May 15, 2017), https://datasociety.net/output/media-manipulation-and-disinfoonline/. 17-20.

${ }^{9}$ Viren Swami et al., "Conspiracist Ideation in Britain and Austria: Evidence of a Monological Belief System and Associations between Individual Psychological Differences and Real-World and Fictitious Conspiracy Theories," British Journal of Psychology 102, no. 3 (2011): 443-63, https://doi.org/10.1111/j.2044-8295.2010.02004.x.

10 Matthew R.X. Dentith, The Philosophy of Conspiracy Theories(New York, NY: Palgrave Macmillan, 2014), 14-18.

${ }^{11}$ Karen M. Douglas and Robbie M. Sutton, "The Hidden Impact of Conspiracy Theories: Perceived and Actual Influence of Theories Surrounding the Death of Princess Diana," The Journal of Social Psychology 148, no. 2 (April 1, 2008): 210-22, https://doi.org/10.3200/SOCP.148.2.210-222

${ }^{12}$ Adrienne Trier-Bieniek, "Framing the Telephone Interview as a Participant-Centred Tool for Qualitative Research: A Methodological Discussion," Qualitative Research 12, no. 6 (December 1, 2012): 630-44, https://doi.org/10.1177/1468794112439005. 
come to the conclusion that it is inappropriate-even potentially harmful-to refer to interview participants as "conspiracy theorists," or even "conspiracists," as I have done in previous work. Rather, I now refer to them as "people who research topics that have been labeled "conspiratorial,"” or, much more succinctly, "researchers." To discuss the type of research they engage in, or the topics themselves, I will use the term "alternative" or "controversial."

Why the need to avoid the terms "conspiracy theorist" and "conspiracy theory"? These terms are complex, delicate, and often ill-defined. At its broadest and most basic, a conspiracy involves a group of people planning something in secret. A conspiracy theory is any speculation about an event that alleges conspiratorial causes for that event. ${ }^{13}$ Following this, a conspiracy theorist can be considered to be anyone who alleges that a conspiracy has taken place. This seems straightforward at first glance, but the term has become so loaded in modern parlance that its sociocultural signifiers bear examination.

Many scholars who study conspiracy theorizing, including such canonical voices as Richard Hofstadter ${ }^{14}$ and Karl Popper, ${ }^{15}$ discuss the topic as though it is inherently problematic. Other scholars, like Lance deHaven-Smith and Matthew R.X. Dentith, question this stance. Certainly, politicians and other powerful figures can and do weaponize the pejorative nature of the label "conspiracy theorist," by branding critics and dissenters as such. According to deHaven-Smith, using the label as a general putdown for people who are mistrustful or critical of government can damage the proper functioning of democracy. Such rhetoric is based in the notion that elected officials never collude. Both deHaven-Smith and Dentith argue that not all conspiracy theories should be labeled as such or considered on equal footing-instead, each theory must be considered and analyzed on a case-by-case basis, according to the evidence presented in support of it. ${ }^{16}$

These two approaches to the study of conspiracy theory are repeatedly identified by scholars in the field: Dentith himself designates the former camp as generalists and the latter as particularists. Thomas Milan-Konda designates the former as the "negative" camp, which sees conspiracy theorizing as primarily a psychological issue, and the "positive" camp, which sees it as a primarily sociological issue. ${ }^{17}$ Klein et al. likewise differentiate between the "monological" viewpoint and what they call the "iceberg model." The monological viewpoint considers conspiracy theorists as a group that can be evaluated according to shared socio-psychological characteristics, whereas the iceberg model suggests that conspiracy theorists who fit the monological viewpoint are just the tip of the iceberg--below the surface lie those who are much more epistemically and psychologically heterogeneous. ${ }^{18}$

\footnotetext{
${ }^{6}$ Dentith, The Philosophy of Conspiracy Theories, 15.

${ }^{14}$ Richard Hofstadter, "The Paranoid Style in American Politics," in The Paranoid Style in American Politics and Other Essays (New York, NY: Random House: Vintage Books, 2008).

${ }^{15}$ Karl Popper, The Open Society and Its Enemies: The High Tide of Prophecy: Hegel, Marx, and the Aftermath, 5th ed., vol. 2 (London, UK: Routledge, 1974).

${ }^{16}$ Matthew R.X. Dentith, "When Inferring to a Conspiracy Might Be the Best Explanation," Social Epistemology 30, no. 5-6 (2016): 572-91, http://dx.doi.org/10.1080/02691728.2016.1172362.

${ }_{17}$ Milan Konda, Conspiracies of Conspiracies, 5.

18 Colin Klein, Peter Clutton, and Vince Polito, "Topic Modeling Reveals Distinct Interests within an Online Conspiracy Forum," Frontiers in Psychology 9 (2018), https://doi.org/10.3389/fpsyg.2018.00189.
} 
Many generalists, including Hofstadter ${ }^{9}$ and Sunstein and Vermeule, ${ }^{10}$ have gestured toward the notion that conspiracy theorists seek information in unique ways.

Hofstadter ${ }^{11}$ suggests that the way in which "paranoid" individuals conduct research works against expanding their worldview, and in fact isolates them even further from differing viewpoints. Sunstein and Vermeule ${ }^{12}$ argue similarly that the online environment has enabled conspiracists to form "epistemologically isolated groups or networks." However, the authors make this assessment without any meaningful research into such communities. Are all research communities that form around socalled "conspiratorial" topics epistemically isolated, as Sunstein and Vermeule assume they must be? Or is there regular engagement with outside and/ or challenging viewpoints?

Seeking information outside of one's research community is an exercise in vulnerability for all researchers, but especially for those who research topics that have been labeled "conspiratorial." It is thus doubly important for information professionals and reference personnel to build trusting relationships with such researchers. Of particular import as I explore this topic during the COVID-19 pandemic: how might trust between reference personnel and researchers be built in the online environment? Is it even possible to do so? Further, how might the unique research practices of these populations contribute to a more nuanced understanding of information seeking as epistemically diverse? 


\section{References}

Aaronovitch, David. Voodoo Histories: The Role of the Conspiracy Theory in Shaping Modern History. New York, NY: Riverhead Books, 2010.

Braitch, Jack. Conspiracy Panics: Political Rationality and Popular Culture. Albany, New York: State University of New York Press, 2008.

Brotherton, Rob. Suspicious Minds. New York, NY: Bloomsbury Sigma, 2015.

Dentith, Matthew R.X. The Philosophy of Conspiracy Theories. New York, NY: Palgrave Macmillan, 2014.

Douglas, Karen M., and Robbie M. Sutton. "The Hidden Impact of Conspiracy Theories: Perceived and Actual Influence of Theories Surrounding the Death of Princess Diana." The Journal of Social Psychology148, no. 2 (April 2008): 210-21. https://doi.org/10.3200/SOCP.148.2.210-222.

Garrett, R. Kelly, Daniel Sude, and Paolo Riva. "Toeing the Party Lie: Ostracism Promotes Endorsement of Partisan Election Falsehoods." Political Communication 0, no. 0 (October 11, 2019): 1-16.https://doi.org/10.1080/10584609.2019.1666943.

Harambam, Jaron, and Stef Aupers. "Contesting Epistemic Authority: Conspiracy Theories on the Boundaries of Science." Public Understanding of Science 24, no. 4 (May 1, 2015): 466-80.https://doi.org/10.1177/0963662514559891.

Harambam, Jaron, and Stef Aupers. "I Am Not a Conspiracy Theorist': Relational Identifications in the Dutch Conspiracy Milieu." Cultural Sociology 11, no. 1 (March 1, 2017): 113-29. https://doi.org/10.1177/1749975516661959.

Hofstadter, Richard. "The Paranoid Style in American Politics." In The Paranoid Style in American Politics and Other Essays. New York, NY: Random House: Vintage Books, 2008.

Jane, Emma A., and Chris Fleming. Modern Conspiracy: The Importance of Being Paranoid. New York, NY: Bloomsbury Academic, 2014.

Klein, Colin, Peter Clutton, and Vince Polito. "Topic Modeling Reveals Distinct Interests within an Online Conspiracy Forum." Frontiers in Psychology 9 (2018). https://doi.org/10.3389/fpsyg.2018.00189.

Marwick, Alice, and Rebecca Lewis. "Media Manipulation and Disinformation Online." Data \& Society Research Institute, May 15, 2017. https://datasociety.net/output/media-manipulation-and-disinfo-online/.

Milan Konda, Thomas. Conspiracies of Conspiracies: How Delusions Have Overrun America. Chicago, IL: University of Chicago Press, 2019. 
Popper, Karl. The Open Society and Its Enemies: The High Tide of Prophecy: Hegel, Marx, and the Aftermath. 5th ed. Vol. 2. London, UK: Routledge, 1974.

Sunstein, Cass R., and Adrian Vermeule. "Conspiracy Theories: Causes and Cures*." Journal of Political Philosophy17, no. 2 (2009): 202-27. https://doi.org/10.1111/j.1467-9760.2008.00325.x.

Swami, Viren, Rebecca Coles, Stefan Stieger, Jakob Pietschnig, Adrian Furnham, Sherry Rehim, and Martin Voracek. "Conspiracist Ideation in Britain and Austria: Evidence of a Monological Belief System and Associations between Individual Psychological Differences and Real-World and Fictitious Conspiracy Theories." British Journal of Psychology102, no. 3 (2011): 443-63. https://doi.org/10.1111/j.2044-8295.2010.02004.x.

Trier-Bieniek, Adrienne. "Framing the Telephone Interview as a Participant-Centred Tool for Qualitative Research: A Methodological Discussion." Qualitative Research 12, no. (December 1, 2012): 630-44. https://doi.org/10.1177/1468794112439005. 
